EA 4272

\title{
Housing and location choices of retiring households: Evidence from France
}

\author{
Laurent GOBILLON $\left(^{*}\right)$ \\ François - Charles WOLFF $\left.{ }^{* *}\right)$
}

$2009 / 32$

$\left({ }^{*}\right)$ INED

$\left.{ }^{* *}\right)$ LEMNA, Université de Nantes, CNAV et INED, Paris

INSTITUT d'ECONOMIE et de MANAGEMENT de NANTES - IAE
Laboratoire d'Economie et de Management Nantes-Atlantique Université de Nantes

Chemin de la Censive du Tertre - BP 52231 44322 Nantes cedex 3 - France

www.univ-nantes.fr/iemn-iae/recherche

Tél. +33 (0)2 40141719 - Fax +33 (0)2 40141749 


\title{
Housing and location choices of retiring households: Evidence from France ${ }^{\#}$
}

\author{
Laurent Gobillon *
}

\author{
François-Charles Wolff ${ }^{* *}$
}

September 2009

\begin{abstract}
In this paper, we study the mobility and housing choices of the elderly when retiring using household data collected in France. From a theoretical viewpoint, retirees are likely to decrease their housing quantity because of an income loss when retiring, but they may also increase it to benefit from more housing comfort for leisure. Using the 1992 Trois Générations survey, we first show that housing mobility at retirement is substantial in France, with a variety of self-reported motives. Then, using the 1994-2001 French Europanel survey, we find evidence of both upsizing and downsizing for mobile recent retirees. In many cases, housing adjustments lead to a correction of the initial disequilibrium between the number of rooms and the number of occupants. However, a significant proportion of mobile recent retirees improve the quality of their dwelling.

Keywords: retirement, housing, mobility, panel data, France
\end{abstract}

JEL Classification: J26, R21

\footnotetext{
\# We are indebted to Harris Selod for his insightful comments on a previous draft. We also would like to thank Tim Halliday, Andy Mason, Sang Hyop Lee, and seminar participants at Ined (Paris), University of Hawaï (Manoa), the 23èmes Journées de Microéconomie Appliquée (Nantes), Cergy, Nancy, Marseille (GREQAM), Strasbourg (BETA) and CEE (Paris). Any remaining errors are ours.

* Corresponding author. INED, PSE, CREST and CEPR. INED, 133 Boulevard Davout, 75980 Paris Cédex 20, France. Tel: 0033 (0) 1560620 16. Email: laurent.gobillon@,ined.fr http://laurent.gobillon.free.fr/

${ }^{* *}$ LEMNA, Université de Nantes, France; CNAV and INED, Paris, France.

Email: wolff@sc-eco.univ-nantes.fr http://www.sc-eco.univ-nantes.fr/ fcwolff
} 


\section{Introduction}

In many European countries, housing markets are getting tighter over the years, the main market indicators like housing prices, transactions or mortgages showing strong growth except over the very recent period. It is well acknowledged that both macroeconomic and demographic factors have a deep influence on the housing markets (Hardman and Ioannides, 1995). In particular, many countries are beginning to experience a great demographic transition because of the baby-boom. The high fertility rates after the Second World War have resulted in a high concentration of people born between 1946 and 1964. This is currently leading to an increase in the number of people who retired, a phenomenon whose impact is so far not fully appreciated. This surge should have both economic and social implications on housing markets. It therefore matters to understand the housing decisions of people who retired.

Although the housing choices of the population as a whole have been widely analyzed, the literature on housing in later life is less developed. Some papers have studied the living arrangements and the informal care from children to parents when sharing a home (Börsch-Supan et alii, 1992; Hoerger et alii, 1996; Pezzin and Schone, 1999). The intergenerational co-residence was considered as a mode of assistance to the elderly. A few papers have rather looked at the dynamics of housing adjustments in later life, especially at retirement.

As retirement goes along with a loss of income and a rise in leisure time, significant housing and location changes are expected. Feinstein and McFadden (1989) and Venti and Wise (1990) find that mobility is high at retirement in the United States. Ermisch and Jenkins (1999) investigate the determinants of residential mobility for the elderly in Britain as well as the subsequent housing adjustments made by movers using the first five waves of the BHPS. They consider the whole population aged 55 and over as moves are scarce in later life. However, this makes them unable to disentangle the effect of retirement on housing adjustments from the effect of widowhood or a spouse getting unemployed. Subsequent more recent studies on European countries have used the same kind of approach (Tatsiramos, 2006; Laferrère, 2005).

The purpose of our contribution is to investigate in details the housing and location choices of retiring people using household data collected in France. Our analysis departs from most existing studies, which have proposed some general analyses of housing adjustments in later life and have not really focused on retirement issues only. To motivate our empirical analysis, we begin with a theoretical discussion and show that individuals may want to either increase or 
decrease their dwelling size and quality when retiring if they decide to move. These inconclusive predictions occur because of the trade-off between the loss of income and additional leisure time which follow retirement. To shed light on housing adjustments, we rely on the following two French datasets. First, we use the 1992 Trois Générations cross-section survey to compute some descriptive statistics on residential mobility when retiring and on self-reported motives for moving. Various reasons are given by retiring individuals to motivate their move, including living closer to the family, finding a place with a better climate, and changing the size of the dwelling. We then study more closely the mobility process and housing adjustments using the 1994-2001 French Europanel survey. We show that about $60 \%$ of movers decide to move at the exact retirement date or one year later. There is evidence of both upsizing and downsizing for mobile recent retirees. Housing adjustments mostly lead to a correction of the initial disequilibrium between the number of rooms and the number of occupants. However, a significant proportion of mobile recent retires improve the quality of their dwelling.

The rest of this paper is organized as follows. In Section 2, we discuss the housing choices when retiring and the related literature. In Section 3, we present our results on the selfreported motives of respondents for moving at retirement. In Section 4, we investigate more closely the timing of residential mobility and consider the various housing adjustments made by movers using panel data. Finally, Section 5 concludes.

\section{Theoretical background}

The purpose of this section is to present the mechanisms explaining the mobility and housing choices when retiring. First, consider the schematic case of an individual holding a job whose earnings are used for the consumption of some goods and the payment of housing costs. Retirement has two main consequences on the different constraints faced by the agent. On the one hand, the individual income switches from his wage to a lower retirement pension. This negative income effect makes him likely to decrease his consumption of goods and creates some pressure to reduce the housing cost by downsizing. On the other hand, the new retiree benefits from more leisure time. Hence, he values more his dwelling as he can spend more time at home.

Given these changes in financial and time constraints, the retiree can choose between staying in his dwelling and moving. If he stays, he cannot adjust his dwelling to his new retirement needs. If he moves, he can do such adjustments, but mobility involves a moving cost. 
There are some monetary costs like transportation fees and transaction costs when selling a house. There are also some utility losses as the social capital of movers is likely to be lost (DiPasquale and Glaeser, 1999). Private benefits stemming from a localized network of friends clearly decrease when moving to another location.

In this setting, the individual moves only if the benefits derived from a housing adjustment are worth incurring the moving costs. This implies that the optimal dwelling size once retiring has to be far enough below or above the optimal dwelling size when working for the individual to decide to move (Gobillon and Le Blanc, 2004; Flavin and Nakagawa, 2008). If the two dwelling sizes are close, the individual prefers to stay in his dwelling. Note that size is not the only dimension that the individual can adjust when moving. There are also many qualitative aspects for a dwelling, like bath, toilets, central heating, garden, etc. These extra-dimensions will be considered in our empirical application.

Of course, there are many variations to this schematic example. For instance, the mobility of a couple is typically a joint decision which depends on the labour status of the two partners. When one of them retires and the other one keeps working (in particular because it is mandatory in France to work until a given age which is often 60 to get a full pension), the two spouses may decide to stay in their dwelling and wait for the two partners to be retired before moving. The location of the job position then plays as an anchor.

Also, a household can choose between renting and owning when moving. The literature usually considers that this choice depends on the relative user cost of the two alternatives. ${ }^{1}$ For a renter, the user cost is the rent. For an owner, it includes the maintenance costs and a possible opportunity cost if the return of financial assets (in which the household could have invested the value of the purchased property) is larger than the return of the housing property (that depends on the increase in housing prices). Households often need to borrow on the credit market to purchase a dwelling. However, those reaching the age of retirement have had time to accumulate wealth. Many are already owners and can sell their house and use the money as a down payment when purchasing a new dwelling. Note however that there are some non-negligible notary expenses when buying a house. As the life horizon is shorter for retirees than for instance a young couple which tries to access ownership, these expenses may deter some retirees to buy a new house.

\footnotetext{
${ }^{1}$ The tenure choice has been widely studied in the literature (see Henderson and Ioannides, 1983; Linneman and Wachter, 1989; Zorn, 1989; Gobillon and Le Blanc, 2008).
} 
Housing choices also depend on the preferences of households for consumption and leisure in the present, which may have influenced their saving behaviour when they were on the labour market. We can illustrate the effect of these preferences on the mobility behaviour when retiring with two polar cases. First consider an individual who wants to consume and spend a significant amount of time in leisure. He tends to consume a lot and may rent a large house when working. He does not save much and may be short of money when retiring. He is then expected to downsize. Now consider an individual who wants to accumulate some wealth that he may enjoy later and chooses to occupy a time-consuming job. He does not consume much and lives in a small dwelling for which he pays a low rent while working. When retiring, he has some wealth which can be used for his leisure time and is then expected to upsize his dwelling.

Also, some households may prefer to spend time outside their dwelling rather than inside. In that case, they are less likely to upsize their dwelling, but may invest more in a garden. Location matters and movers may choose places that propose consumption amenities such as a nice weather, an access to the coast or an enjoyable countryside. It is considered since Roback (1982) that the levels of rents and wages compensate for the presence of consumption amenities. Indeed, places where there are some amenities should be characterized at the spatial equilibrium by some lower wages or some higher rents. As retirees are not on the labour market anymore, they are more attracted by places where consumption amenities are compensated by low wages (Knapp and Graves, 1988). Such places include large spaces where the weather is nice and the occupation of land is not much constrained, as for instance locations in more rural areas of the South or South West (in départements like Ardèche, Lot, etc). By contrast, nice spots on the coast are likely to exhibit high rents as the occupation of land is constrained and they may thus attract only wealthy retirees. Some papers have shown that retired people have a strong preference for living in sunny areas (Hogan and Steinnes, 1998; King et alii, 1998; Chen and Rosenthal, 2008). Retirees also have more time to spend with their children and grandchildren, and they may choose to live closer to their family (De Coulon and Wolff, 2006). ${ }^{2}$

The location choice is expected to affect the housing adjustments of the households. On the one hand, downsizing is likely if the housing costs are very high on the site of destination or if the climate is very nice there and the individuals intend to spend a lot of time outside. On the

\footnotetext{
${ }^{2}$ While retirees certainly enjoy spending time with their children and caring for their grandchildren, providing informal care to disabled elderly parents may be a very cumbersome and unpleasant task. There may be then some incentives for young retirees to move far away from their parents (Konrad et alii, 2002).
} 
other hand, upsizing is more likely if housing costs are very low on the site of destination or if the climate is bad.

To summarize, our discussion shows that the theoretical predictions on housing adjustments when retiring are not clear-cut and the housing choices of households thus clearly remain an empirical question. Using two French datasets, we investigate in the next two sections the pattern of self-reported motives for the moving decision as well as the adjustments of housing size and quality of mobile households.

\section{The pattern of self-reported motives for mobility}

As highlighted in the previous section, several reasons may explain mobility when retiring. We shed some light on these reasons using self-reported motives given by respondents in the survey Trois Générations (3G hereafter). This survey was conducted in 1992 by the French old-age pension fund and its aim was to provide a better understanding of the dynamics of family relationships.

The data set is based on a sample of randomly selected families including at least three adult members of consecutive generations living in France (see Jellal and Wolff, 2002). The sample was constructed first selecting some adults born between 1939 and 1943 having at least one parent and one adult child alive. From the information on location that these adults provided, one of the parents and one of the adult children were then interviewed using the same questionnaire. The sample comprises 1,958 middle-aged adults, 1,217 grandparents and 1,493 young adults.

We restrict our attention to the grandparents, who were aged between 68 and 92 years in 1992 and have thus retired. ${ }^{3}$ The respondents provide detailed information on their characteristics (biography, income, health among others), their current dwelling and their relationships with other generations. The survey also includes a retrospective question about residential mobility at the date of retirement: "Did you move when you retired (or when your spouse retired) or during the two or three years after retirement?". When a household moves, we have some information

\footnotetext{
${ }^{3}$ As most of them are born between 1910 and 1920, this generation has experienced little unemployment, but did not benefit from the spread of education observed in France after World War II (Attias-Donfut and Wolff, 2005).
} 
on the new location, i.e. whether the respondent lives in the same region or in a different region. ${ }^{4}$

A first finding is that mobility at retirement is a significant phenomenon in France: $31.5 \%$ of grandparents claim that they moved when retiring. Among them, 55.9\% stayed in the same region, while $44.1 \%$ relocated in another region. The survey also includes a retrospective question on the motive for moving. Respondents can choose one motive only in a list of several reasons that can be divided into five broad categories: family, geography, work, housing and other motives. A drawback of this self-reported information is that moving may have multiple causes. Also, more emotional reasons like going back to the place of birth or family motives may be selected more often than economic factors.

In Table 1, we report descriptive statistics on the main reason given by retired respondents for their move. First, $16.5 \%$ of them claim that they wanted to live closer to other family members. Most often, retirees intended to find a dwelling near their children. Two reasons can explain this choice. Parents may enjoy visiting their children and providing them with grandchild care (Cardia and Ng, 2003, Dimova and Wolff, 2006). Parents may also want to live near their children to benefit from upstream resources at old age. ${ }^{5}$ A change in the housing size is quoted by $15.5 \%$ of movers. This item can be related to the sub-optimality of housing size or quality when retiring and a need for housing adjustments to reach the new optimum. Interestingly, the proportion of respondents who moved to a larger dwelling is nearly the same as the proportion of respondents who moved to a smaller dwelling.

\section{Insert Table 1 here}

Reasons related to geography are reported by $9.2 \%$ of respondents. Among them, some mobile retirees are mainly motivated by going back to their place of birth, while others are more interested in migrating to a sunny place like the South or the South-West of France. A substantial fraction of mobile retirees $(29.1 \%)$ claims that they have moved for a professional reason. This can be explained in several ways. First, people suffer from a loss in income when retiring. The most financially constrained may not have enough money to stay in their current dwelling, especially if they are renters. Also, some respondents may have access to a free furnished

\footnotetext{
${ }^{4}$ A shortcoming here is that we do not have any detailed information on the previous and current location. The reference to the region may have different interpretations depending on the respondent's feeling on their place of residence before and after the move.

${ }^{5}$ It should be kept in mind that the focus of the survey is on tri-generational families, for which there are private transfers both in the upward and downward directions. The family motive is thus likely to be overrepresented in our sample.
} 
apartment while holding a job, or they may benefit from a partial funding for their housing from their employer. All these benefits are lost when retiring. ${ }^{6}$ Finally, the residual "other motives" category (for which we do not have any additional information) is quoted by many respondents $(29.8 \%)$.

In Table 2, we investigate whether individual characteristics are correlated with the selfreported motives for moving. As retirees are interviewed several years after experiencing mobility, we focus on more permanent characteristics (gender, educational attainment) as well as on retrospective questions (occupational status in activity, living in couple when retiring). We also use the current level of income of the household as a proxy for resources after retirement.

\section{Insert Table 2 here}

According to the $3 \mathrm{G}$ survey, women and people living alone when retiring put forward some family motives much more frequently. This is not surprising as respondents can visit their children more easily when living closer to their place of residence. Motives related to geography are mainly reported by mobile retirees who are highly educated, executives, and with a high level of income. Living in a sunny place on the coast (in cities like Biarritz, Cannes or Nice) is usually costly and could deter households who are not wealthy to move there.

When moving at retirement, farmers and self-employed people have to give up their previous dwelling more often than workers with another occupation. This should be due to the sale of the workplace that often includes the living place. Employees and blue collars report a change in the size of the dwelling more often than self-employed and highly-educated respondents. Housing adjustments exhibit different patterns depending on income. A downsizing motive is reported by $14.6 \%$ of respondents in the first quartile of income, while the proportion is only $2.9 \%$ in the fourth quartile. Conversely, an upsizing motive is quoted by only $4.2 \%$ of respondents in the first quartile compared to $12.5 \%$ in the fourth quartile.

\section{Panel evidence on mobility and housing adjustments}

\subsection{The French Europanel survey}

We study housing adjustments using the Europanel survey conducted in France over the 1994-2001 period. It is a longitudinal survey on households carried out by the French Institute of

\footnotetext{
${ }^{6}$ Farmers and self-employed are for instance expected to sell their workplace when retiring, and their dwelling is often part of the workplace.
} 
Statistics, whose aim is to provide some comparable information for several European countries. It starts with the interview of 7,344 households in 1994. These households are then tracked across the different waves even if they move. The sample size significantly decreases over time due to attrition, but the decrease has a magnitude similar to the one observed for other national longitudinal surveys (Perracchi, 2002). ${ }^{7}$

At each wave, the survey provides for every household the date of arrival in the current dwelling. It also includes the location of that dwelling, its size (area in squared meters), its number of rooms, its equipment, whether it is a house or a flat, and whether the household is homeowner or renter. Very detailed information is available on the quality and the surroundings of the dwelling: whether the dwelling is too noisy, too dark, in poor condition or in need for repairs, whether there is some pollution or vandalism in the surrounding area, etc.

We construct two different samples to study the housing choices when retiring. The first one includes all the observations related to the individuals who retire during the panel period. ${ }^{8}$ We call it the retiring sample. We assume that age at retirement cannot be below 50 and the few observations violating this criterion were deleted. This leaves us with a sample of exactly 627 individuals $(3,892$ person-year observations). The focus of this sample is on at-risk individuals, since the selected respondents retired during the panel period. Nevertheless, some uncertainty remains on the measure of mobility at retirement even when using this restricted sample. For instance, we do not have any information on moves just after retirement for individuals retiring at the end of the panel. Also, some people in the panel claim that they are inactive at 55 and are still so eight years after. Although these people may certainly be considered as retired over 60 years (which is in many cases the mandatory date for retirement in France), they are not included in our retiring sample.

Our second sample, called the elderly sample, is based on a simple age criterion. We keep observations only for people aged between 55 and 70 when first interviewed. This allows us to make a comparing between our results and those obtained for Britain by Ermisch and Jenkins (1999) who selected individuals aged 55 and older. Nevertheless, contrary to these authors, we put an upper bound on the age interval. We can thus avoid moves to nursing homes that may

\footnotetext{
${ }^{7}$ For instance, the number of households is 6,722 in 1995 and 5,343 in 2001.

${ }^{8}$ To select these observations, we construct at each date a variable indicating the occupational status. Then, we keep only the observations of individuals who report they were occupied in the first interview and possibly later, but were retired at the time of their last interview or before.
} 
occur in particular because of disability. This second sample includes 3,029 individuals corresponding to 15,491 person-year observations. The number of observations is far larger than in the retiring sample, which can be helpful as mobility of the elderly remains rather scarce. However, retiring people are not as well targeted as with the retiring sample.

\subsection{Factors influencing residential mobility}

We first describe the magnitude of residential mobility. Using the retiring sample, we find that the average annual mobility rate is $3.4 \%$ (see Table 3 ). The annual mobility rate is lower for the elderly sample, as it reaches only $2.5 \%$. Ermisch and Jenkins (1999) obtain a slightly higher rate (3.3\%) using their sample of people aged 55 and over extracted from the British Household Panel Survey (BHPS). Our mobility rate is also much lower than the one observed in the United States (Feinstein and McFadden, 1989). It is well acknowledged that housing mobility is less important in France than in other countries. Finally, simple calculations show that the proportion of people moving at least once during the panel period is equal to $18.8 \%$ when using the retiring sample (and $11.7 \%$ when using the elderly sample). ${ }^{9}$

\section{Insert Table 3 here}

It is not surprising to find a lower propensity to move when using the elderly sample as all observations are not necessarily at risk. In particular, some individuals in this sample are already retired at the beginning of the panel and they may have made a move related to retirement before the first survey date. In both the elderly and retiring samples, mobile respondents usually make one move only during the 1994-2001 period (Table 3). Using the retiring sample, we find that $88.1 \%$ of mobile respondents move once, $10.2 \%$ of them move twice and only $1.7 \%$ of them move three times. Multiples moves may be caused by the dissatisfaction with a new dwelling, or the unintended inheritance of some housing assets.

We now describe the timing of residential mobility for movers. We only consider movers of the retiring sample who are in the panel at least two years before retirement and are still observed two years after retirement. We examine whether these movers leave their current dwelling just after retirement or whether they anticipate retirement either by moving before

\footnotetext{
${ }^{9}$ The proportion of movers is lower in the Europanel than in the $3 \mathrm{G}$ survey. This can occur because the period of reference is not the same, as we use a retrospective question on retired people in the $3 \mathrm{G}$ survey. Also, in the $3 \mathrm{G}$ survey, a move at retirement is reported for an individual whether he or his partner retired. Finally, attrition may reduce the proportion of movers in the Europanel survey.
} 
retirement. In Figure 1, we represent the distribution of these movers over the five-year period that begins two years before retirement. We find a peak of residential mobility at the year of retirement: $43 \%$ of mobile individuals move exactly the same year as they retire. The proportion of moves made one year after retirement is also quite high, as it stands at $26 \%$. Conversely, only $17 \%$ of moves occur during the two years before retirement. The lower tail of the distribution exhibits an increasing profile. These results support the fact that the residential mobility observed in our sample is related to retirement. ${ }^{10}$

\section{Insert Figure 1 here}

As owning additional housing assets is likely to favour mobility, we study the role of secondary home ownership on the mobility decision. In Table 4, we report the proportion of movers between the dates $t-1$ and $t$ depending on whether individuals own a secondary home or not in $t-1$ and $t$. We find that the proportion of movers is much higher for those owning an additional home in $t-1$, but not in $t$. These findings suggest that at retirement, mobile people who own some additional housing assets before their move choose to live in their secondary home after their move.

\section{Insert Table 4 here}

We also estimate Probit models to highlight the variables which influence the decision to move between dates $t-1$ and $t$. We use the elderly sample and observations are defined on an individual-year basis. ${ }^{11}$ According to Table 5, the probability of moving is higher for "younger" respondents and for those being married in $t-1$, while gender, number of dependent children and limitations of daily activities for health reasons do not have any significant effect. Mobility is higher for highly-educated respondents. This is certainly due to a permanent wealth effect as income in $t-1$ plays no role. Mobility is clearly related to the retirement decision. The probability of moving is much higher when retiring between $t-1$ and $t$, but mobility is not significantly affected by retirement between $t-2$ and $t-1$.

\section{Insert Table 5 here}

Having a working spouse working in $t-1$ strongly reduces the probability of moving. This

\footnotetext{
${ }^{10}$ Additional results (not reported here) show that it is difficult to explain the timing of residential mobility. For instance, the gender, marital status, income, homeownership and size of the previous dwelling do not influence the timing of the mobility decision. However, individuals who were farmers or self-employed during their working life move more often at the exact date of retirement. When retiring, farmers and self-employed stop renting their jobrelated assets if they are renters, or sell their workplace if they are owner. Also, owners who sell their equipment tools have some liquid assets that can be used to purchase a new dwelling.
} 
is not surprising as costs incurred when moving are probably much higher. Housing conditions also play an important role in the mobility process of the elderly. Living in a house in $t-1$ reduces the probability of moving. Interestingly, we do not find any significant effect of number of excess rooms (which is defined as the number of rooms minus the number of persons living in the household). Thus, mobility would not be mainly driven by adjustments of the dwelling size, and other factors such as location or housing quality may matter more. We find that the duration of residence and being an owner have a large negative effect on mobility. Mobility costs are higher for owners as they have to incur some significant transaction costs and tend to over-invest in local amenities and social capital (DiPasquale and Glaeser, 1999).

Table 5 also reports the estimates of Probit regressions for each housing status in $t-1$. Results show that there are some differences between renters and owners. Indeed, the influence of retirement on the probability of moving is much higher for renters than for owners. It may be that renters are those who move the most during their career and wait until retirement to choose a stable location. Alternatively, renters may be unable to pay their rent after retirement as their income decreases. We also find that the duration of residence has a significant effect only for renters, which may be due to rent control. After a few years, the rent paid by a renter is likely to be far below the market rent.

\subsection{Housing adjustments}

We now study the housing adjustments of movers. Specifically, we assess whether the households increase or decrease the size and quality of their dwelling as the theory on this issue leads to inconclusive predictions. Since individuals are tracked over time in the Europanel survey, we are able to compare their housing situation in $t$ with the one in $t-1$.

In Table 6, we compare the size of the dwelling before and after moving. We report for a given housing status and number of excess rooms in $t-1$, the change in the number of excess rooms for movers. We obtain very similar results for owners and renters. When the number of excess rooms is zero or negative, individuals tend to increase the size of their dwelling when moving. When the number of excess rooms is at least three, households choose to reduce the size of their dwelling. ${ }^{12}$

\footnotetext{
${ }^{11}$ The standard errors of the Probit estimates are adjusted for clustering at the individual level.

${ }^{12}$ An interesting feature is the peak observed for homeowners with exactly two rooms in excess in $t-1$ deciding to move. Most of them choose to maintain this number of excess rooms after their move. As in France, the average
} 


\section{Insert Table 6 here}

We then estimate Probit models on the subsample of movers to evaluate the effect of the number of rooms in $t-1$ on the change in the number of excess rooms, all else being equal. We run two separate regressions. The first one explains the decrease in the number of excess rooms, while the second one explains the increase in the number of excess rooms. Results reported in Table 7 show that there is a "downsizing" effect for movers previously living in a dwelling which was large compared to the number of people living in, while there is an "upsizing" effect for movers previously living in a dwelling which was small.

Hence, our results suggest that in France, elderly people tend to correct their initial disequilibrium position when retiring. This finding is in accordance with the results described in Ermisch and Jenkins (1999) for Britain. Nevertheless, it should be kept in mind that adjusting the size of the dwelling was not a key factor when explaining mobility (see Table 4). It is only when retirees have decided to move for one among various reasons that they take the opportunity to choose a more appropriate number of rooms given their situation.

\section{Insert Table 7 here}

We also study the changes in housing quality using two sets of variables. The first one includes all housing equipments both in $t-1$ and in $t$. If there is on average an improvement of the equipment when moving, one should observe a higher transition rate for the cell "not in $t-1$, present in $t$ " than for the cell "present in $t-1$, not in $t$ ". Results reported in Table 8 suggest that mobile respondents tend to move to dwellings that are better equipped. First, the few households who did not have very basic equipments (bath, shower, warm water, etc) move to dwellings equipped with them. Secondly, households tend to access better heating systems after moving, in particular central heating or electric fires. Third, mobile households have more often access either to a terrace or to a non-vegetable garden after their move. ${ }^{13}$

\section{Insert Table 8 here}

The second set of variables characterizes the problems faced by households when living in their home. There may be some problems related to the dwelling itself such as the dwelling being too dark, too noisy, poorly heated, or with materials in bad conditions (non-isolated

number of children is two, it may be that movers keep a large dwelling to lodge their children when they are visiting.

${ }^{13}$ After a move, we note that fewer respondents have access to an independent kitchen. However, the interpretation of this result is intricate. Indeed, in many modern dwellings, the kitchen is part of the living room, so that having an independent kitchen does not mean living in a higher quality dwelling. 
windows for instance). As shown by Table 8, all these problems occur much less frequently after moving. For instance, $13 \%$ of respondents report that their dwelling was too dark in $t-1$ but is not in $t$, while only $3 \%$ of them have a darker dwelling in $t$. There may also be some insecurity or pollution problems in the neighbourhood. Again, movers tend to escape these negative externalities. For instance, $20.6 \%$ of movers claim that there were insecurity and vandalism problems in their neighbourhood in $t-1$, but do not report this kind of troubles in $t$. Conversely, only $5 \%$ of individuals live in an insecure place after moving whereas it was not the case before their move.

We then examine whether movers are renters or owners in $t$ depending on their housing tenure in $t-1$ (Table 9). We find that the housing tenure before moving plays a major role: $65 \%$ of mobile households who were renters in $t-1$ are still renters in $t$ and $35 \%$ have accessed ownership. Conversely, $86 \%$ of mobile owners are also owners of their new dwelling in $t$. The inertia in the owner status may result from intrinsic preferences for homeownership. Also, homeowners who sell a dwelling have some liquid assets that can be used to purchase another dwelling. The lower inertia in the renter status may be explained by some specific mobility behaviours of renters during the working period. People who move frequently because of their professional occupation sometimes choose to rent a dwelling as mobility is much easier in that case. These renters may wait for retirement to purchase a dwelling.

\section{Insert Table 9 here}

We can also assess from Table 9 whether movers choose to live in a flat or a house in $t$ depending on their type of dwelling in $t-1$. We find that transitions from a flat to a house are rather frequent and account for $45.5 \%$ of respondents living in a flat in $t-1$. Conversely, most of the respondents occupying a house in $t-1$ choose to live in a house again in $t$. This may be due to a wealth effect as houses are mostly in ownership. Indeed, homeowners can use the money they get from selling their previous house to purchase another house. It is clearly more interesting to choose a house rather than a flat as there is more privacy and less trouble from neighbours when living in an independent house. Moreover, there is often a garden going along with a house, which makes it more valuable.

We also find that retiring individuals are likely to go to more pleasant areas when changing their location. A significant proportion of movers choose to leave the Paris region when retiring. While about $18 \%$ of mobile households resided in this region before moving, the 
proportion reduces to $12.8 \%$ after moving. In Paris, housing is much more expensive than elsewhere in France and even if the city is characterized by unique cultural features, it is somewhat polluted by fumes and loud noises from all sources. According to the data, the most attractive areas (i.e. those where retirees are more likely to live after moving) are mainly located in the South-West and in the South of France. ${ }^{14}$ Finally, mobile respondents tend to move to smaller municipalities after retiring. For instance, the proportion of mobile households living in rural areas (less than 2,000 inhabitants) is $27 \%$ before moving and $31 \%$ after moving.

\section{Conclusion}

In this paper, we have analyzed the mobility and housing choices of retiring people in France. These issues are especially relevant for that country given the ongoing and forthcoming retirement of the large cohorts of baby-boomers born in the 1950s and 1960s. From a theoretical viewpoint, individuals may want to either increase or decrease their housing when retiring. This is because retirees suffer from a loss of income due to retirement and moving costs, but have more leisure time and thus value housing more.

Using two French data sets, we have shown that residential mobility is substantial when retiring and that various motives like housing adjustments, climate and family location are put forward by mobile households for their move. The use of panel data provides additional results on residential mobility at retirement. Our main conclusions are that mobile people mainly choose to move the year they retire and that housing conditions (including location) are often better after moving. Furthermore, housing adjustments most often lead to a correction of the initial disequilibrium position since "downsizing" is mainly observed for movers previously living in a dwelling with some excess rooms, while "upsizing" is more frequent for movers whose living space is constrained.

Several extensions to our contribution may come to mind. Firstly, one could gather and use detailed information on housing prices and rents to account for their role in the moving decision. Secondly, it would be of interest to compare the residential mobility and motives for moving of workers and retirees. Upsizing is on a priori grounds more likely among young adult workers because of births and wealth accumulation. Also, young workers can certainly not afford to move to sunny places on the coast as housing there is usually costly. Thirdly, comparative

\footnotetext{
${ }^{14}$ On average, these areas are more sunny and located near the sea.
} 
evidence on residential mobility in European countries could help to better understand migration inflows of retirees from Northern to Southern European countries. In some areas of Mediterranean Europe, international migrations at retirement clearly have some large effects on regional economic geography (King et alii, 1998).

Finally, it could be worth assessing the direct impact of the residential mobility of retirees on the housing-market prices. Indeed, prices are likely to increase in places with consumption amenities where retirees tend to move (such as places characterized by a sunny weather). This in turn could prevent younger households to locate there. A general equilibrium framework is clearly needed to better understand this kind of mechanisms and more generally all the consequences of a demographic shock like the baby-boom on housing decisions. We leave this issue for future research. 


\section{References}

Attias-Donfut C., Wolff F.C. (2005), "Generational memory and family relations", in M. Johnson, V. Bengtson, P. Coleman, T. Kirkwood (eds), The Cambridge Handbook of Age and Ageing, Cambridge University Press.

Börsch-Supan A., Hajivassiliou V., Kotlikoff L., Morris J. (1992), "Health, children, and elderly living arrangements", in D.A. Wise, (ed.), Topics in the Economics of Aging, University of Chicago Press, Chicago, pp. 79-103.

Cardia E., Ng S. (2003), "Intergenerational time transfers and childcare", Review of Economic Dynamics, vol. 6, pp. 431-454.

Chen Y., Rosenthal S. (2008), "Local amenities and life-cycle migration: Do people move for jobs or for fun?", Journal of Urban Economics, vol. 64, pp. 519-537.

De Coulon A., Wolff F.C. (2006), "The location of immigrants at retirement: Stay/return or 'va-et-vient' ?", IZA Discussion Paper, n 2224.

Dimova R., Wolff F.C. (2006), "Does grandchild care enhance maternal labor supply? Evidence from around Europe", IZA Discussion Paper, n 2469.

DiPasquale D., Glaeser E.L. (1999), "Incentives and social capital: Are homeowners better citizens ?", Journal of Urban Economics, vol. 45, pp. 354-384.

Ermisch J., Jenkins S. (1999), "Retirement and housing adjustment in later life: evidence from the British Household Panel Survey", Labour Economics, vol. 6, pp. 311-333.

Feinstein J., McFadden D. (1989), "The dynamics of housing demand by the elderly: wealth, cash flow, and demographic effects", in D.A. Wise, (ed.), Economics of Aging, University of Chicago Press, Chicago, pp. 55-91.

Flavin M., Nakagawa S., (2008), "A model of housing in the presence of adjustment costs: A structural interpretation of habit persistence", American Economic Review, vol. 98, pp. 474-495.

Gobillon L., Le Blanc D. (2004), "L'impact des contraintes d'emprunt sur la mobilité résidentielle et les choix de statut d'occupation des ménages : un modèle simple de demande", Annales d'Economie et de Statistique, 74, pp. 15-46.

Gobillon L., Le Blanc D. (2008), "Economic effects of upfront subsidies to ownership: the case of the Prêt à Taux Zéro in France", Journal of Housing Economics, vol. 17, pp. $1-33$.

Hardman A.M., Ioannides Y.M. (1995), "Moving behaviour and the housing market", Regional Science and Urban Economics, vol. 25, pp. 21-39.

Henderson V., Ioannides Y. (1983), "A model of housing tenure choice", American Economic Review, vol. 73, pp. 98-113.

Hoerger T., Picone G., Sloan F. (1996), "Public subsidies, private provision of care and living arrangements of the elderly", Review of Economics and Statistics, vol. 78, pp. 428-440. 
Hogan, T., Steinnes, D. (1998), "A logistic model of the seasonal migration decision for elderly households in Arizona and Minnesota", Gerontologist, vol. 38, pp. 152-158.

Jellal M., Wolff F.C. (2002), "Cultural evolutionary altruism : Theory and evidence", European Journal of Political Economy, vol. 18, pp. 241-262.

King, R., Warnes, A.M., Williams, A.M. (1998), "International retirement migration in Europe", International Journal of Population Geography, vol. 4, pp. 91-111.

Graves P., Knapp. (1988), "Mobility behavior of the elderly", Journal of Urban Economics, vol. 24, pp. 1-8.

Konrad K.A., Kunemund H., Lommerud K.E., Robledo J.R. (2002), "Geography of the family", American Economic Review, vol. 92, pp. 981-998.

Laferrère A. (2005), "Old age and housing: dissaving, adjusting consumption, and the role of children", mimeographed, INSEE.

Linneman P., Wachter S.M. (1989), "The impacts of borrowing constraints on homeownership", AREUEA Journal, vol. 17, pp. 389-402.

Perrachi F., (2002), “The European Community Household Panel: A review”, Empirical Economics, vol. 27, pp. 63-90.

Pezzin L.E., Schone B.S. (1999), "Intergenerational household formation, female labor supply and informal caregiving. A bargaining approach", Journal of Human Resources, vol. 34, pp. 475-503.

Roback J. (1982), "Wages, Rents and the Quality of Life", Journal of Political Economy, vol. 90, pp. 1257-1278.

Tatsiramos K. (2006), "Residential mobility and housing adjustment of older households in Europe”, IZA Discussion Paper, $\mathrm{n}^{\circ} 2435$.

Venti S.F., Wise D.A. (1990), "But they don't want to reduce housing equity", in D.A. Wise, (ed.), Issues in the Economics of Aging, University of Chicago Press, Chicago, pp. 13-29.

Zorn P.M. (1989), "Mobility-tenure decisions and financial credit: Do mortgage qualification requirements constrain homeownership?", AREUEA Journal, vol. 17, pp. 1-16. 
Table 1. Self-reported motives for moving

\begin{tabular}{|l|r|}
\hline Self-reported motive & $\%$ \\
\hline Family motive & 16.5 \\
To live closer to parents & 1.8 \\
To live closer to children & 14.7 \\
Geographic motive & 9.2 \\
To live closer to origin country & 6.3 \\
To live in a sunny area & 2.9 \\
Professional motive & 29.1 \\
Housing motive & 15.5 \\
To live in a larger dwelling & 7.9 \\
To live in a smaller dwelling & 7.6 \\
Other motive & 29.8 \\
\hline Number of observations & 383 \\
\hline
\end{tabular}

Source: 1992 Trois Générations Survey. 
Table 2. Self-reported motives for moving, by respondent's characteristics

\begin{tabular}{|c|c|c|c|c|c|c|c|c|}
\hline \multirow{2}{*}{\multicolumn{2}{|c|}{ Variable }} & & \multicolumn{5}{|c|}{ Motive for mobility } & \multirow[t]{2}{*}{$\mathrm{Chi}^{2}$ (prob) } \\
\hline & & & Family & Geographic & Professional & Housing & Other & \\
\hline \multicolumn{9}{|c|}{ Gender } \\
\hline & Male & $(\mathrm{N}=107)$ & 10.3 & 11.2 & 30.8 & 15.0 & 32.7 & 4.69 \\
\hline & Female & $(\mathrm{N}=276)$ & 18.8 & 8.3 & 28.3 & 15.6 & 29.0 & $(0.321)$ \\
\hline \multicolumn{9}{|c|}{ Living in couple } \\
\hline & No & $(\mathrm{N}=96)$ & 21.9 & 5.2 & 19.8 & 14.6 & 38.5 & 11.34 \\
\hline & Yes & $(\mathrm{N}=287)$ & 14.6 & 10.5 & 32.1 & 15.7 & 27.2 & $(0.023)$ \\
\hline \multicolumn{9}{|c|}{ Education } \\
\hline & No education & $(\mathrm{N}=174)$ & 14.9 & 5.2 & 25.9 & 20.1 & 33.9 & 26.02 \\
\hline & Primary & $(\mathrm{N}=142)$ & 19.7 & 10.6 & 34.5 & 12.7 & 22.5 & $(0.011)$ \\
\hline & Above primary & $(\mathrm{N}=66)$ & 12.1 & 16.7 & 25.8 & 9.1 & 36.4 & \\
\hline \multicolumn{9}{|c|}{ Occupation } \\
\hline & Farmer & $(\mathrm{N}=66)$ & 9.1 & 3.0 & 40.9 & 10.6 & 36.4 & 57.45 \\
\hline & Self-employed & $(\mathrm{N}=53)$ & 9.7 & 7.6 & 56.6 & 7.6 & 18.9 & $(0.000)$ \\
\hline & Executive & $(\mathrm{N}=46)$ & 13.0 & 17.4 & 23.9 & 13.0 & 32.6 & \\
\hline & Employee & $(\mathrm{N}=96)$ & 22.9 & 5.2 & 20.8 & 21.9 & 29.2 & \\
\hline & Blue collar & $(\mathrm{N}=82)$ & 15.9 & 12.2 & 17.1 & 22.0 & 32.9 & \\
\hline & Inactive & $(\mathrm{N}=40)$ & 27.5 & 15.0 & 22.5 & 7.5 & 27.5 & \\
\hline \multicolumn{9}{|c|}{ Income } \\
\hline & Quartile 1 & $(\mathrm{~N}=96)$ & 10.4 & 6.3 & 30.2 & 18.8 & 34.4 & 12.27 \\
\hline & Quartile 2 & $(\mathrm{~N}=84)$ & 21.4 & 8.3 & 29.8 & 11.9 & 28.6 & $(0.424)$ \\
\hline & Quartile 3 & $(\mathrm{~N}=98)$ & 21.4 & 7.1 & 28.6 & 15.3 & 27.6 & \\
\hline & Quartile 4 & $(\mathrm{~N}=105)$ & 13.3 & 14.3 & 27.6 & 15.2 & 29.5 & \\
\hline Total & & $(\mathrm{N}=383)$ & 16.5 & 9.2 & 29.1 & 15.5 & 29.8 & - \\
\hline
\end{tabular}

Source: 1992 Trois Générations Survey. 
Table 3. The magnitude of residential mobility

\begin{tabular}{|l|c|c|}
\hline Variables & $\begin{array}{c}\text { Individuals retiring } \\
\text { during the panel }\end{array}$ & $\begin{array}{c}\text { Individuals between } 55 \text { and } 70 \\
\text { when first interviewed }\end{array}$ \\
\hline Among the movers & $88.1 \%$ & $90.9 \%$ \\
1 move & $10.2 \%$ & $8.5 \%$ \\
2 moves & $1.7 \%$ & $0.6 \%$ \\
3 moves & $3.4 \%$ & $2.5 \%$ \\
Annual movement rate & $(\mathrm{N}=3892)$ & $(\mathrm{N}=15491)$ \\
Proportion of movers & $18.8 \%$ & $11.7 \%$ \\
& $(\mathrm{~N}=627)$ & $(\mathrm{N}=3029)$ \\
\hline
\end{tabular}

Source: 1994-2001 Europanel Survey. 
Table 4. Distribution of individuals, by moving decision and secondary home ownership in $t-1$ and $t$

\begin{tabular}{|c|c|c|}
\hline Moving in $t$ & & \\
\hline & & \\
\hline Owns a secondary home in $t-1$ & No & Yes \\
\hline No & $48.3 \%$ & $7.6 \%$ \\
\hline Yes & $22.0 \%$ & $22.0 \%$ \\
\hline Not moving in $t$ & & \\
\hline & & \\
\hline Owns a secondary home in $t-1$ & No & Yes \\
\hline No & $73.3 \%$ & $4.5 \%$ \\
\hline Yes & $4.5 \%$ & $17.7 \%$ \\
\hline
\end{tabular}

Source: 1994-2001 Europanel Survey.

Note: for each category (moving and not moving), the four percentages sum to $100 \%$. 
Table 5. Determinants of residential mobility between years $t-1$ and $t$

\begin{tabular}{|c|c|c|c|}
\hline Variables & All & Renters in $t-1$ & Owners in $t-1$ \\
\hline \multirow[t]{2}{*}{ Constant } & -0.228 & 0.561 & -0.672 \\
\hline & $(0.49)$ & $(0.75)$ & $(1.07)$ \\
\hline \multirow[t]{2}{*}{ Female } & 0.008 & -0.107 & 0.063 \\
\hline & $(0.15)$ & $(1.26)$ & $(0.92)$ \\
\hline \multirow[t]{2}{*}{ Age in $t-1$} & $-0.019 * * *$ & $-0.023 * * *$ & $-0.023 * * *$ \\
\hline & $(3.46)$ & $(2.68)$ & $(2.98)$ \\
\hline \multirow[t]{2}{*}{ Married in $t-1$} & $0.182 * * *$ & 0.054 & $0.329 * * *$ \\
\hline & $(2.89)$ & $(0.65)$ & $(3.31)$ \\
\hline \multirow[t]{2}{*}{ Number of dependent children in $t-1$} & -0.035 & -0.072 & -0.014 \\
\hline & $(0.95)$ & $(1.31)$ & $(0.25)$ \\
\hline \multirow[t]{2}{*}{ Health limits daily activities in $t-1$} & 0.041 & 0.007 & 0.072 \\
\hline & $(0.81)$ & $(0.09)$ & $(1.05)$ \\
\hline \multicolumn{4}{|l|}{ Education (ref: no diploma) } \\
\hline \multirow[t]{2}{*}{ Primary } & 0.114 & $0.252 * * *$ & -0.075 \\
\hline & $(1.64)$ & $(2.65)$ & $(0.78)$ \\
\hline \multirow[t]{2}{*}{ Vocational } & 0.110 & $0.371 * * *$ & -0.102 \\
\hline & $(1.23)$ & $(2.88)$ & $(0.81)$ \\
\hline \multirow[t]{2}{*}{ High school } & $0.221 * *$ & $0.603 * * *$ & -0.086 \\
\hline & $(2.06)$ & $(3.59)$ & $(0.59)$ \\
\hline \multirow[t]{2}{*}{ Undergraduate } & $0.230 * *$ & 0.211 & 0.062 \\
\hline & $(2.30)$ & $(1.17)$ & $(0.50)$ \\
\hline \multirow[t]{2}{*}{ Graduate, postgraduate } & $0.265 * * *$ & $0.619 * * *$ & -0.171 \\
\hline & $(2.67)$ & $(4.20)$ & $(1.20)$ \\
\hline \multirow[t]{2}{*}{ Retiring between $t-1$ and $t$} & $0.441 * * *$ & $0.578 * * *$ & $0.368 * * *$ \\
\hline & $(4.52)$ & $(3.69)$ & $(2.75)$ \\
\hline \multirow[t]{2}{*}{ Retiring between $t-2$ and $t-1$} & 0.183 & 0.271 & 0.139 \\
\hline & $(1.43)$ & $(1.35)$ & $(0.78)$ \\
\hline \multirow[t]{2}{*}{ Spouse working in $t-1$} & $-0.322 * * *$ & $-0.463 * * *$ & $-0.326^{* *}$ \\
\hline & $(3.23)$ & $(2.95)$ & $(2.39)$ \\
\hline \multirow[t]{2}{*}{ Household income in $t-1(\log )$} & 0.016 & -0.013 & 0.029 \\
\hline & $(0.87)$ & $(0.35)$ & $(1.55)$ \\
\hline \multirow[t]{2}{*}{ In a house in $t-1$} & $-0.336 * * *$ & 0.155 & $-0.763 * * *$ \\
\hline & $(3.97)$ & $(1.38)$ & $(6.96)$ \\
\hline \multirow[t]{2}{*}{ Number of excess rooms in $t-1$} & -0.017 & $-0.081 *$ & 0.034 \\
\hline & $(0.77)$ & $(1.94)$ & $(1.20)$ \\
\hline \multirow[t]{2}{*}{ Duration in residence in $t-1(10 \mathrm{e}-2)$} & $-0.489 * * *$ & $-1.548 * * *$ & 0.183 \\
\hline & $(2.62)$ & $(4.85)$ & $(0.83)$ \\
\hline Home ownership in $t-1$ & $\begin{array}{c}-0.496 * * * \\
(7.54)\end{array}$ & & \\
\hline Number of observations & 13267 & 3058 & 10209 \\
\hline Pseudo $\mathrm{R}^{2}$ & 0.081 & 0.092 & 0.079 \\
\hline Log likelihood & -1369.4 & -575.7 & -731.3 \\
\hline
\end{tabular}

Source: 1994-2001 Europanel Survey.

Probit models with robust standard errors, adjusted for clustering at the individual level. The different regressions also include 8 regional dummy variables and 5 dummy variables related to the size of the area. Absolute value of robust t-statistics are in parentheses, and significances levels are respectively $10 \%(*)$, $5 \%(* *)$ and $1 \%(* * *)$. 
Table 6. Change in excess rooms among movers, by number of excess rooms (row percentages)

\begin{tabular}{|c|c|c|c|}
\hline \multirow[b]{2}{*}{ Number of excess rooms in $t-1$} & \multicolumn{3}{|c|}{ Adjustment in the number of rooms between $t-1$ and $t$} \\
\hline & Decrease & Same & Increase \\
\hline$\leq 0$ & 0.0 & 44.1 & 55.9 \\
\hline 1 & 22.8 & 43.9 & 33.3 \\
\hline 2 & 34.0 & 38.3 & 27.7 \\
\hline$\geq 3$ & 68.4 & 15.8 & 15.8 \\
\hline \multicolumn{4}{|l|}{ Owner in $t$} \\
\hline \multirow[b]{2}{*}{ Number of excess rooms in $t-1$} & \multicolumn{3}{|c|}{ Adjustment in the number of rooms between $t-1$ and $t$} \\
\hline & Decrease & Same & Increase \\
\hline$\leq 0$ & 0.0 & 35.3 & 64.7 \\
\hline$\overline{1}$ & 18.5 & 40.7 & 40.7 \\
\hline 2 & 19.4 & 64.6 & 16.1 \\
\hline$\geq 3$ & 72.4 & 17.2 & 10.3 \\
\hline
\end{tabular}

Source: 1994-2001 Europanel Survey. 
Table 7. Determinants of decrease/increase in number of excess rooms

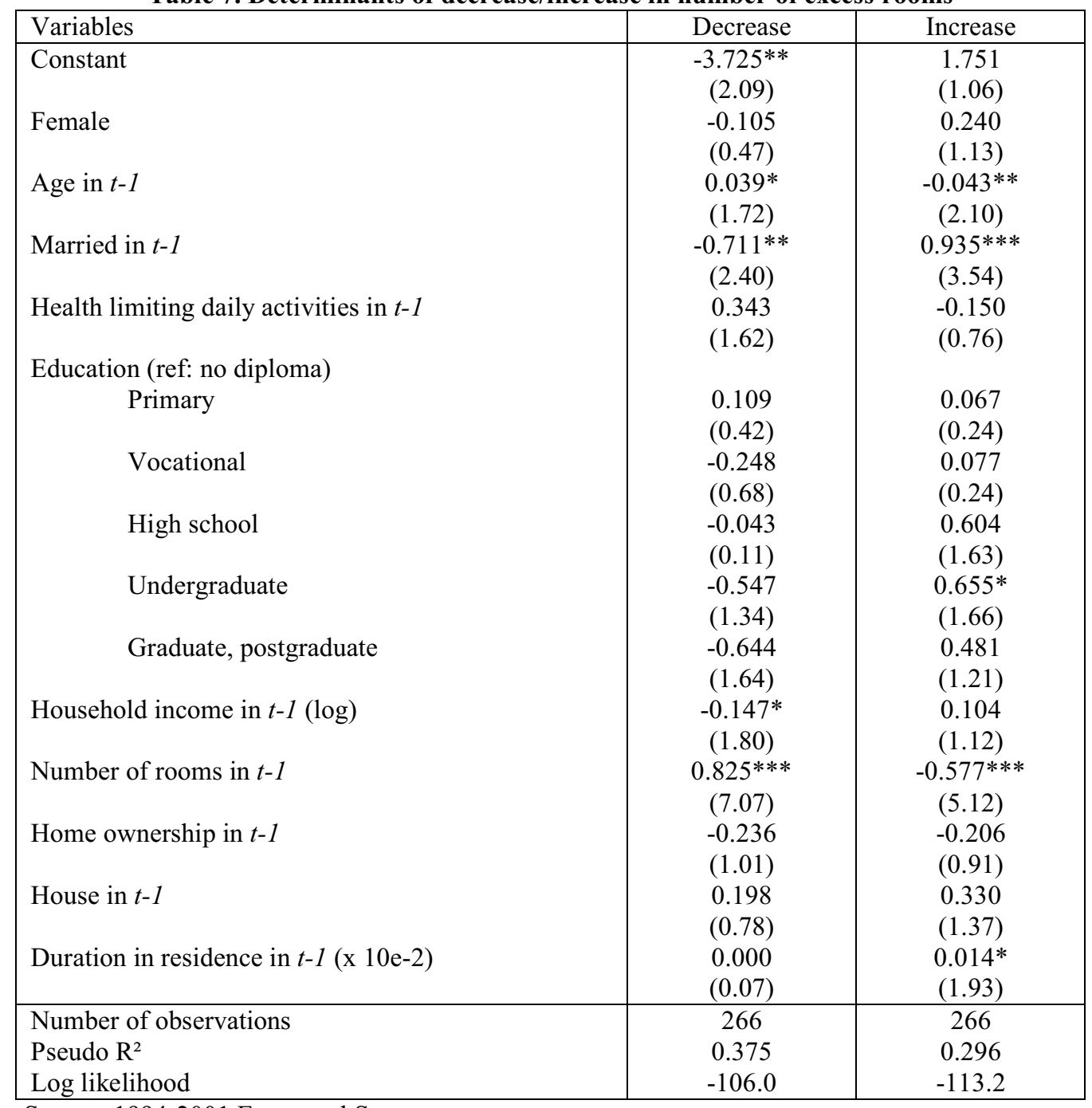

Source: 1994-2001 Europanel Survey.

Probit models with robust standard errors. The different regressions also include 8 regional dummy variables. Absolute value of robust t-statistics are in parentheses, and significances levels are respectively $10 \%(*), 5 \%(* *)$ and $1 \%(* *)$. 
Table 8. Changes in housing conditions for movers (rows percents)

\begin{tabular}{|l|c|c|c|c|}
\hline Changes & $\begin{array}{c}\text { Not in } t-1, \\
\text { not in } t\end{array}$ & $\begin{array}{c}\text { Not in } t-1, \\
\text { present in } t\end{array}$ & $\begin{array}{c}\text { Present in } t-1, \\
\text { not in } t\end{array}$ & $\begin{array}{c}\text { Present in } t-1, \\
\text { present in } t\end{array}$ \\
\hline Housing equipment & 2.4 & 4.8 & 11.0 & 81.7 \\
Independent kitchen & 92.7 & 1.4 & 5.9 & 0.0 \\
Rooms for professional use & 0.0 & 6.6 & 0.0 & 93.5 \\
Bath, shower & 0.0 & 4.8 & 0.3 & 94.8 \\
WC in the housing & 0.3 & 4.8 & 0.0 & 94.8 \\
Warm running water & 10.4 & 18.7 & 11.5 & 59.4 \\
Central heating & 60.0 & 16.2 & 11.7 & 12.1 \\
Electric fires & 36.2 & 16.2 & 24.8 & 22.8 \\
Other means of heating & 18.9 & 22.1 & 14.8 & 44.5 \\
Non-vegetable garden, terrace & & & & \\
Problems faced by the housing & 80.6 & 6.2 & 12.3 & 0.9 \\
Housing too small & 84.6 & 2.8 & 10.5 & 2.2 \\
Noisy neighbours & 67.3 & 9.6 & 17.9 & 5.3 \\
Noisy surroundings & 84.0 & 3.1 & 13.0 & 0.0 \\
Dwelling too dark & 84.3 & 4.4 & 9.4 & 1.9 \\
Inefficient heating & 89.2 & 2.8 & 8.1 & 0.0 \\
Leak in the roof & 76.1 & 4.7 & 17.4 & 1.9 \\
Damp on the walls, on the floor & 83.6 & 2.5 & 13.0 & 0.9 \\
Windows or floor in bad condition & 74.3 & 7.4 & 13.9 & 4.3 \\
Pollution, heavy traffic & 70.1 & 5.0 & 20.6 & 4.4 \\
Insecurity, vandalism & & &
\end{tabular}

Source: 1994-2001 Europanel Survey. 
Table 9. Tenure and housing transition among movers (row percentage)

Tenure transition

\begin{tabular}{|c|c|c|}
\hline \multirow[b]{2}{*}{ Tenure in $t-1$} & \multicolumn{2}{|c|}{ Tenure in $t$} \\
\hline & Renter & Owner \\
\hline Renter & 65.0 & 35.0 \\
\hline Owner & 13.7 & 86.3 \\
\hline \multicolumn{3}{|l|}{ Housing-type transition } \\
\hline \multirow[b]{2}{*}{ Type in $t-1$} & \multicolumn{2}{|c|}{ Type in $t$} \\
\hline & Flat & House \\
\hline Flat & 54.5 & 45.5 \\
\hline House & 26.0 & 74.0 \\
\hline
\end{tabular}

Source: 1994-2001 Europanel Survey. 
Figure 1. Age profile of residential mobility for movers

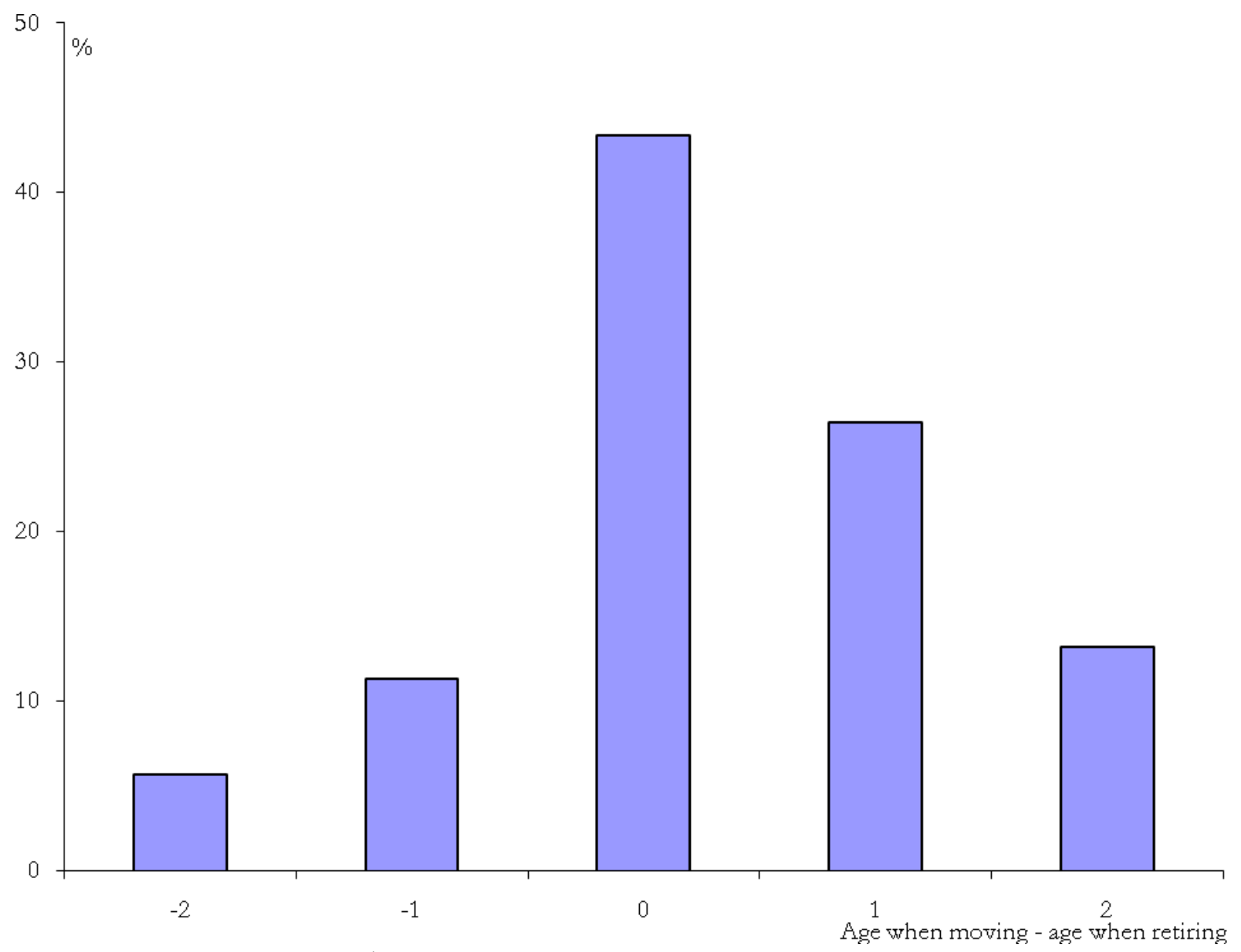

Source: 1994-2001 Europanel Survey. 